\title{
The Availability of Question Analysis on Higher Order Thinking of Physic Textbook in The Concept of Rigid Body
}

\author{
Arini Nur Chayati, Erina Hertanti, Ai Nurlaela \\ Syarif Hidayatullah State Islamic University Jakarta, Jl. Ir. H. Djuanda 95, Ciputat, Indonesia \\ Corresponding e-mail: ariniainain@gmail.com
}

\begin{abstract}
The purpose of this research is to analyze the availability of questions on higher order thinking that was developed in textbook in the concept of rigid body. The textbook selected for this research is the most physics textbook used in the high school in South Tangerang in the terms of 2015/2016, that the most textbook used is, the textbook from Marthen Kanginan (book I) and the textbook from Tim Kreatif Fisika (book II). The research method we used is descriptive method with triangulasi data technique analysis. Using the instrument of non-test such as questionnaire, interview guidance, and observation sheets. Analysis result shows that the availability of question on higher order thinking in book I (Marthen Kanginan's book) was 51,6\% and in book II (Tim Kreatif Fisika's book) was 26,5\%. The percentage indicated that book I (Marthen Kanginan's book) was dominated by the questions that developed higher order thinking and book II (Tim Kreatif Fisika's book) was dominated by the questions that developed lower order thinking.
\end{abstract}

Keywords: questions analysis, physics textbook, higher order thinking

\section{INTRODUCTION}

Ministerial Regulation National Education 2006 High School Standards Competence Graduate said that one of education purpose is to show the analysis and solving ability (2006: 344). According to Bloom cognitive taxonomy revised that analysis and solving ability are included higher order thinking involving three cognitive process, such as analyze $\left(\mathrm{C}_{4}\right)$, evaluate $\left(\mathrm{C}_{5}\right)$, and create $\left(\mathrm{C}_{6}\right)$ (Anderson and Karthwohl, 2005: 157-158).

Higher order thinking defined the use of wide thinking to discover new challenge (Heong, etal, 2011: 121). Higher order thinking is the ability of complicated thinking to solve the problem using different approaching of different problem and example that have been taught (Thompson, 2008: 97). Higher order thinking should make someone that can connect, manipulate, and transform the knowledge to decide how to solve the problem in the new situation. So that, the students need be guided having the ability.
One of things that can stimulate higher order thinking student is to answer the questions (Hasibuan, 1995: 62). The question stimulates the student for thinking and studying, so the questions have the important role in the learning process (Nasution, 1995: 161). In the learning process, the questions generally are in the textbook.

The textbook should be consisted of questions stimulating student's curiosity, so it practiced their thinking ability. The textbook is the learning media that have the crucial role in education to gain the competence as the learning purpose. (Banowati, 2007: 147). The teacher should choose the textbook wisely in the learning process. However, most the teacher does not notice the textbook as the source study. Based on the beginning study, $50 \%$ textbook in the South Tangerang High School is recommended by the Principle or decided by the School Cooperation so the teacher does not have discretion to choose the textbook that is used.

Based on the competence of High School Physic class XI, the concepts that need higher order thinking are Kinematics by Vector Analysis, Newton Law of 
Gravity, Matter and Energy, Simple Harmonic Motion, Rigid Body, Dynamic Fluid, and Kinetic Theory Gases (BSNP, 2011: 447-448). Among the concepts, the writer take the rigid body concept because the questions are more complicated than other concepts questions. It proved that the survey result of Class XII Science and interview of the Physic Teacher in the South Tangerang High School. The result survey and interview indicated that the questions of rigid body are applicative, so higher order thinking is needed to answer the questions.

Based on the background of the problem, the writer did the researcher "The Availability of Question Analysis on Higher Order Thinking of Physic Textbook in The Concept of Rigid Body". The research problem is "How is the availability of question on higher order thinking in the textbook of the Rigid Body concept?' The research purpose is to analyze the availability of questions on higher order thinking in the textbook of the rigid body concept.

\section{METHOD}

The research is conducted in the terms of 2015/2016 in the South Tangerang. The research method is descriptive method. The descriptive research is the research collecting data by words or pictures but numbers (Emzir, 2010: 3). The data is arranged and analyzed. The analysis is content analysis so that the data is described by table, diagram and narrative description to complete the whole description of the activity (Emzir, 2008: 175).

There are three steps in the research, they are: preparation, execution, and final step. Preparation steps are survey and interview to gain the information of textbook and the concepts that need higher order thinking. Next is the execution, it was encoded data and question analysis of higher order thinking. The final steps are discussion of result data, discussion of conclusion, and research report.

The population of the research is the physic high school textbook. The sampling research is the physics textbook class XI in the South Tangerang. The research sampling is purposive sampling by certain consideration (Sugiyono, 2010: 61). Collecting data techniques are questionnaire filling, observation sheet, and interviewing. The questionnaires are given to the student science class XII, observation sheet is considering cognitive ability that is developed by questions of high school physic textbook class XI in the rigid body concept and the interview of the physic teacher science class XI.

The instrument used the non-test, such as questionnaire, interview guidance, and observation sheet. Data analysis technique is triangulation technique. Analysis data step and data process included analyzing the question type, calculating question percentage of higher order thinking, deciding observation reliability and conclusion.

\section{RESULT}

There are three ways of collecting data, such as giving the questionnaires, interviewing and observing. The questionnaire and interview are to know the most used textbook in High School in South Tangerang and to consider the physic complex concept by the student and the teacher. Meanwhile observation is to decide the question type based on Cognitive Taxonomy Bloom differentiate the question by lower order thinking (cognitive ability $\mathrm{C}_{1}, \mathrm{C}_{2}, \mathrm{C}_{3}$ ) and higher order thinking (cognitive ability $\mathrm{C}_{4}, \mathrm{C}_{5}, \mathrm{C}_{6}$ ).

\section{Data Description of Questionnaires Result and Interview}

The questionnaires result and interview gained the information that the most used physic textbook in high school in the South Tangerang are the textbook from Marthen Kanginan and the textbook from Tim Kreatif Fisika. In addition, it informed that the complex concept of both books is the rigid body. Next, we encoded book I as Marthen Kanginan and book II as Tim Kreatif Fisika.

In calculating the questions within the two books, there are different number questions. There are 186 questions of book I (Marthen Kanginan) and 98 questions of book II (Tim Kreatif Fisika). So the writer analyzed 284 questions. The number of analyzing question can be seen on Table 1 .

Table 1 The Number Questions each Textbook

\begin{tabular}{|l|l|c|c|}
\hline No. & Textbook & Code & $\begin{array}{l}\text { Number } \\
\text { Question }\end{array}$ \\
\hline 1. & $\begin{array}{l}\text { Marthen } \\
\text { Kanginan }\end{array}$ & I & 186 \\
\hline 2. & $\begin{array}{l}\text { Tim Kreatif } \\
\text { Fisika }\end{array}$ & II & 98 \\
\hline \multicolumn{2}{|l|}{ Total } & 284 \\
\hline
\end{tabular}

Next, the writer calculated the question in every part. Every parts are the text (encoded A), the Discussion and Activity (encoded B), the selection questions and Olympic Corner (encoded C), example questions (encoded D), and competence test or evaluation (encoded E). 


\section{Observation Sheet Description Data}

Observation sheet data describe the analysis result. The analysis results are:

\section{Analysis Result Question of Bloom Cognitive Taxonomy}

Analysis result question of Bloom Cognitive Taxonomy show different numbers in every part.

2. Percentage Calculation Result Question Higher Order Thinking

Percentage calculation result question higher order thinking both textbooks can be seen on Table 2 .

Tabel 2 Percentage of Order Thinking Development on Book

\begin{tabular}{|c|c|c|c|c|c|c|c|c|}
\hline \multirow{3}{*}{$\begin{array}{l}\mathbf{N} \\
\mathbf{0} \\
. \\
\end{array}$} & \multirow{3}{*}{\multicolumn{2}{|c|}{$\begin{array}{l}\text { Cogniti } \\
\text { ve } \\
\text { Aspect } \\
\end{array}$}} & \multicolumn{6}{|c|}{ Textbooks } \\
\hline & & & \multicolumn{3}{|c|}{ I } & \multicolumn{3}{|c|}{ II } \\
\hline & & & $f$ & & $\%$ & $f$ & & $\%$ \\
\hline 1 & $\mathrm{C}_{1}$ & \multirow{3}{*}{ రิ } & 1 & \multirow{3}{*}{0} & \multirow{3}{*}{48,4} & 4 & \multirow{3}{*}{2} & \multirow{3}{*}{73,5} \\
\hline 2 & $\mathrm{C}_{2}$ & & 8 & & & 8 & & \\
\hline 3 & $\mathrm{C}_{3}$ & & 1 & & & 0 & & \\
\hline 4 & $\mathrm{C}_{4}$ & \multirow{3}{*}{$\stackrel{\nwarrow}{\S}$} & 6 & \multirow{3}{*}{6} & \multirow{3}{*}{51,6} & 6 & \multirow{3}{*}{6} & \multirow{3}{*}{26,5} \\
\hline 5 & $\mathrm{C}_{5}$ & & & & & & & \\
\hline 6 & $\mathrm{C}_{6}$ & & & & & & & \\
\hline $\mathrm{TO}$ & $\mathrm{AL}$ & & & & 100 & & & 100 \\
\hline
\end{tabular}

3. Calculation Observation Reliability Result

In this activity, the writer reanalyzed of the analysis result deciding cognitive ability every question by observer I and observer II. Both observer analysis results can be seen on contingency table by form "yes" or "no".

Tabel 3a Observer Contingency on Book I

\begin{tabular}{|c|l|c|c|c|}
\hline \multirow{2}{*}{$\overrightarrow{\bar{D}}$} & \multicolumn{3}{|c|}{ Observer II } & \\
\cline { 2 - 5 } & & Yes & No & $\begin{array}{c}\text { Total } \\
\text { Observed }\end{array}$ \\
\cline { 2 - 5 } $\overrightarrow{\bar{D}}$ & Yes & 182 & 4 & 186 \\
\cline { 2 - 5 } & No & - & - & - \\
\cline { 2 - 5 } & $\begin{array}{l}\text { Total } \\
\text { Observed }\end{array}$ & 182 & 4 & 186 \\
\hline
\end{tabular}

Table 3b Observer Contingency on Book II

\begin{tabular}{|c|c|c|c|c|}
\hline \multirow{5}{*}{$\begin{array}{l}\vec{\Delta} \\
\overrightarrow{0} \\
\overrightarrow{0} \\
0 \\
0\end{array}$} & \multicolumn{4}{|c|}{ Observer II } \\
\hline & 1 & Yes & No & $\begin{array}{c}\text { Total } \\
\text { Observed }\end{array}$ \\
\hline & Yes & 94 & 4 & 98 \\
\hline & No & - & - & - \\
\hline & $\begin{array}{l}\text { Total } \\
\text { Observed }\end{array}$ & 94 & 4 & 98 \\
\hline
\end{tabular}

4. Cognitive Aspect Comparison Result by Demanding analysis of Curriculum Competence

Comparing the cognitive aspect is to appropriate the developed cognitive aspect and curriculum competence demand. The comparison result show the compliance percentage of every cognitive aspect on the questions in the textbook of rigid body concept by curriculum competence demand.

In the research of two books, they are being analyzed by the curriculum. Book I (Marthen Kanginan) is 2013 curriculum textbook and book II (Tim Kreatif Fisika) is KTSP (kurikulum tingkat satuan pendidikan) textbook. Percentage result analysis cognitive aspect book I (Marthen Kanginan) will be compared to percentage cognitive aspect demand on indicator of RPP (Rancangan Pelaksanaan Pembelajaran) or Lesson Plan and indicator of basis competence 2013 curriculum. While the percentage result analysis cognitive aspect book II (Tim Kreatif Fisika) will be compare to percentage cognitive aspect demand on indicator of RPP (Rancangan Pelaksanaan Pembelajaran) or Lesson Plan and indicator of basis competence KTSP (kurikulum tingkat satuan pendidikan).

\section{DISSCUSSION}

The analysis result of availability question higher order thinking on the textbook of rigid body concept 51.6\% for book I (Marthen Kanginan) and $26.5 \%$ for book II (Tim Kreatif Fisika). The availability question on higher order thinking book I was $51.6 \%$ indicating the book that was dominated by the question that developed higher order thinking. Moreover, the percentage indicated the availability question of higher order thinking in the book I (Marthen Kanginan) fulfilled RPP of curriculum 2013 demand and basis competence indicator 2013 curriculum.

Meanwhile, book II (Tim Kreatif Fisika) by the availability question higher order thinking was $26.5 \%$ indicated that the textbook dominated by the question that developed lower order thinking. Moreover, the percentage indicated the availability question of higher order thinking in the book II (Tim Kreatif Fisika) fulfilled RPP of KTSP and basis competence indicator KTSP.

The availability question of higher order thinking in the book I (Marthen Kanginan) distribute in every parts such as; the text, discussion and activity, selected question and Olympic corner, example question, and competence test or evaluation. Book II (Tim Kreatif Fisika) distributed the question 
based on higher order thinking that is only on discussion and activity, example test and competence test or evaluation. It indicated that distributing the question of higher order thinking on book I (Marthen Kanginan) is better than book II (Tim Kreatif Fisika).

As the explanation above, the book I (Marthen Kanginan) had $51.6 \%$ question on higher order thinking that means $48.4 \%$ questions were lower order thinking. The percentage value of lower order thinking is simply the basis of developing higher order thinking. Meanwhile, book II (Tim Kreatif Fisika) had 26.5\% questions on higher order thinking that means $73.5 \%$ questions were lower order thinking. The percentage value of availability on lower order thinking is simply the basis of developing higher order thinking.

The book I (Marthen Kangina) had the percentage availability of higher order thinking that is not much different from the availability question of lower order thinking. Meanwhile, the book II (Tim Kreatif Fisika) had lower percentage of the availability question of higher order thinking than the percentage of the availability of lower order thinking. The solution that can be applied of balancing the percentage availability of higher order thinking and the availability lower order thinking in the book II (Tim Keatif Fisika) is to modify the questions of lower order thinking into the questions of higher order thinking or the teacher should apply other source of study as the fulfillment.

\section{CONCLUSION}

The two books that are analyzed, are book I (Marthen Kanginan) and book II (Tim Kreatif Fisika) had different percentage of availability questions on higher order thinking. Analysis result indicated that the availability question on higher order thinking of book I (Marthen Kanginan) 51.6\%. It means that the book was dominated by the questions on higher order thinking. Meanwhile, the availability questions on higher order thinking of book II (Tim Kreatif Fisika) $26.5 \%$. It means that the book was dominated by the question on lower order thinking.

Based on the result analysis above, book I (Marthen Kanginan) had bigger percentage of the availability question on higher order thinking than book II (Tim Kreatif Fisika). However, the analysis result can not informed the ability student of higher order thinking. So that, the writer suggests the continuation research by the purpose to compare the ability student of higher order thinking in the school that used book I (Marthen Kanginan) and book II (Tim Kreatif Fisika)

\section{REFERENCES}

Aksela, Maija., "Supporting meaningful chemistry learning and higher-order thinking through computer-assisted inquiry: a design research approach", Disertasi pada Fakultas Sains Universitas Helsinki Finlandia: 2005. Not published.

Amalia, Rizki., "Penerapan Model Pembelajaran Pembuktian untuk Meningkatkan Kemampuan Berpikir Matematika Tingkat Tinggi Siswa SMA", Tesis pada Universitas Pendidikan Indonesia Bandung: 2013. Not published.

Anderson, Lorin W., and Karthwohl, David R. A Taxonomy For Learning, Teaching, And Assesing: A Revision Of Bloom's Taxonomy Of Education Objective. Pi Lambda Theta. 83, 2005.

Kerangka Landasan untuk

Pembelajaran,Pengajaran, dan Asesmen: Revisi Taksonomi Pendidikan Bloom. Terj. Agung Prihantoro. Yogyakarta: Pustaka Pelajar, 2010 .

Arikunto, Suharsimi. Prosedur Penelitian: Suatu Pendekatan Praktik (Edisi Revisi 2010). Jakarta: PT. Rineka Cipta, 2010.

Dasar-Dasar Evaluasi Pendidikan. Jakarta: Bumi Aksara, Ed. 2, 2012.

Ayvaci, Hakan Sevki., and Turkdogan, Ali. Analysing Science and Technology Course Exam Questions According to Revised Bloom Taxonomy. Journal of Turkish Science Education.7, 2010.

Badan Standar Nasional Pendidikan. Salinan Standar Kompetensi dan Kompetensi Dasar KTSP. Jakarta: Kementrian Pendidikan Nasional, 2011.

Banowati, Eva. Buku Teks dalam Pembelajaran Geografi di Kota Semarang. Jurnal Geografi FIS UNNES. 4, 2007. 
Blosser, Patricia E. How to Ask The Right Questions. The National Science Teachers Association. 2000.

Depdiknas. Pedoman Umum Pemilihan dan Pemanfaatan Bahan Ajar. Jakarta: Dijten Dikdasmenum, 2004.

Dewanto, S., "Meningkatkan Kemampuan Berpikir Matematik Tingkat Tinggi melalui Pembelajaran dengan Pendekatan InduktifDeduktif", Tesis pada Universitas Pendidikan Indonesia Bandung: 2004. tidak dipublikasikan.

Emzir. Metodologi Penelitian Pendidikan Kuantitatif Dan Kualitatif. Jakarta: Raja Grafindo Persada, 2008.

--------. Metodologi Penelitian Kualitatif Analisis Data. Jakarta: Raja Grafindo Persada, 2010.

Frandeska, Wilda., “Analisis Pertanyaan Buku Teks Fisika Yang Digunakan di Kota Tangerang Selatan Berdasarkan Kemampuan Berpikir Kritis Pada Konsep Dinamika Partikel”, Skripsi pada Fakultas Ilmu Tarbiyah Dan Keguruan UIN Syarif Hidayatullah Jakarta: 2014. not published.

Hasibuan, J.J. dan Moedjiono. Proses Belajar Mengajar. Bandung: Remaja Rosdakarya , 1995.

Heong, Yee Mei, et al. The Level of Marzano Higher Order Thinking Skills among Technical Education Students.International Journal of Social Science and Humanity. 1, 2011.

Kamajaya. Cerdas Belajar Fisika untuk Kelas XI. Bandung: Grafindo Media Pratama, 2007.

Kanginan, Marthen. Fisika untuk SMA/MA Kelas XI. Jakarta: Erlangga, 2014.

Karamustafaoglu, Sevilay., et al. Analysis Of Turkish High-School Chemistry-Examination Questions According To Bloom's Taxonomy. Chemistry Education: Research And Practice. 4, 2003.

Karthwohl, David R. A Revision Of Bloom's Taxonomy: An Overview. Theory Into Practice. 41, 2002.

Kemendikbud, Salinan Peraturan Menteri Pendidikan Dan Kebudayaan Republik Indonesia Nomor 59 Tahun 2014. Jakarta:
Kementrian Pendidikan dan Kebudayaan Republik Indonesia, 2014.

Kemendiknas. Salinan Peraturan Menteri Pendidikan Nasional Republik Indonesia Nomor 11 Tahun 2005. Jakarta: Kementrian Pendidikan Nasional, 2005.

----------------. Salinan Peraturan Menteri Pendidikan Nasional Republik Indonesia Nomor 23 Tahun 2006. Jakarta: Kementrian Pendidikan Nasional, 2006.

Kocakaya, Serhat., and Gonen, Selahattin. Analysis Of Turkish High-School Physics-Examination Questions According To Bloom's Taxonomy. Asian-Pacific Forum On Science Learning And Teaching.11, 2010.

Moeloeng, Lexy J. Metodologi Penelitian Kualitatif. Bandung: Remaja Rosdakarya, 1997.

Nasution, S. Didaktik Asas-Asas Mengajar. Edisi 2. Jakarta: Bumi Aksara, Cet. I, 1995.

Prastowo, Andi. Panduan Kreatif Membuat Bahan Ajar Inovatif. Yogyakarta: DIVA Press, 2011.

Ruwanto, Bambang. Asas-asas FisikaSMA Kelas X. Jakarta: Yudhistira, 2007.

Sanjaya, Wina. Penelitian Pendidikan Jenis, Metode dan Prosedur. Jakarta: Kencana Prenada Media Grup, Cet. II, 2014.

Siddiq, Japar., "Analisis Pertanyaan Pada Buku Teks Mata Pelajaran Fisika SMA Kelas X Dalam Konsep Dinamika Partikel Berdasarkan Taksonomi Kognitif Bloom”, Skripsi pada Fakultas Ilmu Tarbiyah Dan Keguruan UIN Syarif Hidayatullah Jakarta: 2012. not published.

Sugiyono. Statistika Untuk Penelitian. Bandung: Alfabeta, Cet. XVI, 2010.

Tarigan, Henry Guntur., dan Tarigan, Djago. Telaah Buku Teks Bahasa Indonesia. Bandung: Angkasa, 2009.

Thompson, Tony. Mathematics Teachers' Interpretation Of Higher Order Thinking In Bloom's Taxonomy. International Electronic Journal Of Mathematics Education. 3, 2008. 
Widodo, Ari. Profil Pertanyaan Guru Dan Siswa

Dalam Pembelajaran Sains. Jurnal Pendidikan dan Pembelajaran. 4, 2006.

Wilkinson, John. A Quantitative Analysis of Physics Textbooks for Scientific Literacy Themes. Reseacrh in Science Education. 12, 1999. 